\title{
Jacques Berlioz, Catastrophes naturelles et calamités au Moyen Age
}

\section{G. Matteo Roccati}

\section{Q OpenEdition}

1 Journals

\section{Édition électronique}

URL : https://journals.openedition.org/studifrancesi/37221

DOI : 10.4000/studifrancesi.37221

ISSN : 2421-5856

Éditeur

Rosenberg \& Sellier

\section{Édition imprimée}

Date de publication : 15 décembre 2004

Pagination : 581

ISSN : 0039-2944

\section{Référence électronique}

G. Matteo Roccati, « Jacques Berlioz, Catastrophes naturelles et calamités au Moyen Age », Studi

Francesi [En ligne], 144 (XLVIII | III) | 2004, mis en ligne le 30 novembre 2015, consulté le 08 mai 2021.

URL : http://journals.openedition.org/studifrancesi/37221 ; DOI : https://doi.org/10.4000/

studifrancesi.37221

Ce document a été généré automatiquement le 8 mai 2021.

\section{(c) 9 (i) $\Theta$}

Studi Francesi è distribuita con Licenza Creative Commons Attribuzione - Non commerciale - Non opere derivate 4.0 Internazionale. 


\title{
Jacques Berlioz, Catastrophes naturelles et calamités au Moyen Age
}

\author{
G. Matteo Roccati
}

\section{RÉFÉRENCE}

JACQUES BERLIOZ, Catastrophes naturelles et calamités au Moyen Age, Firenze, Sismel Edizioni del Galluzzo («Micrologus’ Library», 1), 1998, pp. 244.

1 Le volume rassemble des travaux déjà parus, mais ici remaniés et développés. A côté de deux études de portée générale, sur les calamités naturelles au Moyen Age et sur les récits exemplaires comme sources documentaires, les autres chapitres concernent des points particuliers: les loups dans Paris d'après le Journal d'un bourgeois de Paris, l'effondrement du mont Granier en Savoie en 1248, la catastrophe du lac d'Oisans en 1219, la légende de Ponce Pilate à Vienne en Dauphiné, l'ascension du mont Canigou par Pierre III d'Aragon. A travers l'examen attentif des sources, l'ouvrage a pour ambition de montrer comment les événements ont été perçus et expliqués. Le volume comporte aussi l'index des manuscrits cités et celui des noms de personne et de lieu. 